\title{
THE CREATION AND USE OF THE BODY MACHINE IN THE FIRST TWO DECADES OF THE COMMUNIST RULE IN BULGARIA
}

\author{
LA CREACIÓN Y EL USO DEL CUERPO-MAQUINA EN LAS PRIMERAS \\ DOS DÉCADAS DEL REGIMEN COMUNISTA EN BULGARIA
}

\author{
Gergana Popova ${ }^{1}$ \\ South-West University "Neofit Rilski” (Bulgaria)
}

Recibido: 11-02-2014

Aceptado: 11-10-2014

\begin{abstract}
The paper analyses the communist treatment of labour in Bulgaria in the first two decades after the establishment of the socialist rule. It examines the figure of the worker as an ideal type of communist person. The article also studies the communist negation of idleness and the relation between idleness, sexual corruption and moral disgrace. The main emphasis is laid on the conceptualization of idleness in terms of anti-communist resistance. Also the concept of "body machine" is introduced to reveal some aspects of this extremely high valuation of labour on the one hand, and of the neglect of pleasure on the other hand.
\end{abstract}

Key-words: discipline, body machine, communist bio-politics, labour camps.

Resumen: En el artículo se analiza el trato del trabajo en las dos primeras décadas después del establecimiento de un Estado comunista en Bulgaria. Se examina la figura del trabajador como modelo de persona comunista. También se estudia la negación de la ociosidad así como la relación entre la ociosidad, la corrupción sexual y la desgracia moral. El énfasis principal está puesto en la conceptualización de la ociosidad en términos de resistencia anticomunista. El concepto de "cuerpomaquina" se introduce para revelar algunos aspectos de esta extremadamente alta valoración del trabajo, por un lado, y de la negligencia del placer por otro lado.

Palabras-clave: disciplina, cuerpo-máquina, biopolítica comunista, campos de trabajo.

[1] (gerp@abv.bg) Se doctoró en Estudios culturales por la Universidad de Sofia "San Clemente". Es profesora en la Universidad Sur-Oeste "Neofit Rilski" de Blagoevgrad, Bulgaria. Sus principales líneas de investigación son las nociones totalitarias y post-totalitarias del cuerpo humano y las teorías de bio-política y sexualidad. Algunos de sus publicaciones son "El ascetismo alegre en los conceptos del amor y del erotismo en Bulgaria socialista", "La cultura física de masas y el deporte como maquina comunista de producción de cuerpos disciplinados", "La formación cuidadosa y los cuerpos desobedientes - el disciplinario de los jóvenes en época socialista", "La corporeidad masculina entre las alegorías del heroísmo y la obviedad literal del cuerpo”. 
In the first years after the establishment of the communist rule in Bulgaria in 1944 the new symbolic order is grounded on the inflated by the propaganda memory about the anti-fascist resistance and on the tense current situation of a direct confrontation with the capitalist world. Quite logically what come to the fore are the military values and the mythologizing images of communist heroism. Partisans represent the ideal for communist person; the qualities partisans demonstrated in the battles against fascism are now predicated upon the fight for the imposition of the communist regime ${ }^{2}$. They set the model for communist behaviour. The ideal image of early socialism is the hero in his various hypostases - the beaten, but enduring tortures communist martyr, who, in a quasi-Christian mode of sacrifice, transforms himself in living proof of the authenticity of the ideal; the hardy and tested in battles warrior, who cannot be intimidated by the deprivation and hardships on the way to the bright future; the partisan-ascetic, who even after the victory, finds neither peace and quiet, nor personal joy.

Gradually the semi-military atmosphere of the 1940s brightens up and (in spite of the lingering military rhetoric) this change predetermines the slow transformations in the ideal type of socialist person. The fighters against fascism continue to exercise a dominating influence on society, but rather than being a real model for activism and behaviour, they now have the symbolic role of a sort of mythological corrective and a hierarchically distant - bureaucratized and stylized - authority. The post-revolutionary society now lays new economic and ideological foundations. They are based on a permanent clash with the non-socialist world and on an increasing resistance to foreign influences. This new society claims that it decidedly needs hard-working and efficient individuals. Love for the communist party and fatherland is associated with love for labour, which, logically, becomes a basic communist virtue; all the aspects of socialist morality are invariably defined through the attitude to labour:

„The morality of our society is the morality of workers, it deems labour a highly valued occupation, it praises working people... even such intimate moral values as love, comradeship, family affection are deeply rooted in creative labour" (Vishnyakov 1965: 32)

Thus, what comes to the fore - at least in the first two decades of the establishment of the communist rule - is the figure of the worker, who is almost the unique representative of the whole communist symbolic hierarchical space (that is why most of the other professional strata are metaphorically identified

[2] A serious problem with the denotation of Bulgarian rule and society between 1944 and 1989 exists. The ideologists of the regime called it socialistic society after the interpretation of Marxist theory. This interpretation of socialism as a preceding stage before communism is quite different from the Western usage of the term "socialism". Nevertheless it is used here in the sense it had in Soviet Union and the countries of Eastern bloc. Another term "communist regime" is used to denote the one-party rule of Bulgarian communist party.

THÉMATA. Revista de Filosofía, Nº51 enero-junio (2015) pp.: 325-341

doi: 10.12795/themata.2015.i51.17 
with proletariat - scientific workers, culture workers and so on) ${ }^{3}$. This figure has a few basic epiphenomena:

\section{The hero at work.}

The widespread in the 40s and 50s sintagmas 'labour front', 'labour heroism', 'labour feats' extrapolate well-known military concepts and impose them on representations of labour in daily routines, thus signifying the connection between the builders of the socialist society and the mythological forefathers-partisans, who "gave their lives for the communist idea". The press is interspersed with interviews and reports about shock-workers ${ }^{4}$ that have fulfilled the plan with a Stakhanotive enthusiasm ${ }^{5}$, regardless of the difficulties on the road to the bright future, gladly enduring physical pain and exhaustion at the construction sites. Posters and photos in newspapers reproduce one and the same image of communist workers: strained, single-minded, carrying hammers, pickaxes and breakers, wearing blue overalls and vests, with bulging underneath their clothes muscular shoulders. This typified representation of the worker in all legitimate socialist discourses and in their visual analogues seems to rehabilitate the traditional type of masculinity. The emphasis on the masculine image and conduct of workers in the socialist context, however, possesses certain features:

Those acquainted with the national-socialist representative model recognize a particular iconographic resemblance between the way Hitlerism and socialism treat masculine images. There is a similarity between the blond, blue-eyed, muscular German worker and the fair-haired, bright-eyed and weather-beaten communist worker. While the former exemplifies the cult to the masculine body - a cult, naturally generated within the framework of the ideological paradigm of National Socialism, which focuses primarily on the biological superiority of the Aryan race; the latter is an example of imagery, constructed along the lines of an allegory. The image of the communist worker has the suggestive goal to represent the inevitable future victory of the socialist regime (the worker always looks ahead), the menacing power of the communist party

[3] A specific feature of this attitude is the conceptualization of the figure of the construction worker. The construction worker is placed highly in the internal workers' hierarchy - he is perceived not only as one of the modes of proletarian existence, but also as a global metaphor of the new person who lays the foundations of a whole new world.

[4] The word comes from the collocation "shock work". The notion 'shock worker' is used to designate those workers that exceed the plan well over the norm.

[5] Aleksei Stakhanov (1906 - 1977) is a Soviet mineworker, who, with the help of his colleagues, discovered a method to increase the coal output in his mine. In 1935 he set a record digging out 227 tons of ore during his shift, twice as much as the norm. The Stakhanovite movement was named after him and the aim of this movement was to maximally increase productivity and to prove the advantages of the communist economic system.

THÉMATA. Revista de Filosofía, No 51 enero-junio (2015) pp.: 325-341 doi: 10.12795/themata.2015.i51.17 
(he always clenches his fists), the willpower of the communist (the determined look, the high forehead, the stiff lips). The loyalty to the party occupies the supreme place in the value system of communism. As much as any socialist sign strives to manifest that vital signified in a context that shows a definite subordination of the visual to the oral codes, this sign is to a great extent arbitrary and absolutely dependent on the ideological textual foundation. The images of workers are no exception to the rule - they are typified, deindividualised, demonstrating a strict iconography, determining the poses, gestures, clothes and facial expressions. Stylized to comply with the suitable signifier that demonstrates the strength and power to the communist spirit, they do not represent as much as narrate; they narrate the same text again and again.

The discursive treatment of the worker develops along similar lines. The worker is a central figure in the socialist society. His professional qualities, however, are not seen as a specific set of individual characteristics but as a function of his communist loyalty and the accompanying spiritual qualities.

The socialist masculinity and work efficiency are attributed to the communist spirit, which overcomes bodily weakness and infirmity; they are an essential part of the unconditional dedication to the Party, therefore they cannot be separated from the party's power. Thus, even the weak, unhealthy and crippled body can become efficient if it possesses the necessary fragment of communist spirit. The extreme version of this masculinity is represented in emblematic novels such as "How Steel was Tempered" and "A Novelette of the Real Person", but it is far from limited within the literary genre. Examples of such a radical victory of mind over matter are common for the socialist press:

„The name of Vladimir Kanev - a excavator from the "Alexandar Stamboliyski" dam - is well-known in our country. This humble man is renowned for his heroism on the labour front. In spite of his personal misfortune - he lost his leg in an accident - he continues his work with doubled energy. He became the best excavator at the construction site and was twice awarded the most distinguished order of the People's Republic - the order "George Dimitrov" (To educate the masses in a socialist attitude to labour 1954).

In this radical mode of representation the worker is a natural heir of the resistance hero; the work activity - often (especially after the 1960s) seen

[6] „How Steel was Tempered“ is an autobiographic novel by the Soviet writer Nikolai Ostrovski (1904-1936). It tells the story of a Ukrainian village boy, who, at the age of 15 , takes part in the civil war, supporting the Bolsheviks. Soon he is badly wounded in a battle. At the age of 23 Ostrovski is totally paralysed and blind with both eyes. He starts writing his autobiographic book being absolutely blind. Therefore, he remembers by heart every single word because he cannot see or edit the text. "A Novelette of the Real Person" is written by the Soviet writer Boris Polevoy. The prototype is the Soviet pilot Alexei Meresiev, whose plane crashes during the Second World War; the pilot himself is badly wounded and survives for 18 days in the woods in the winter. He eats berries and roots and moves by crawling on all fours as his legs are broken. After his rescue his legs are amputated but using his willpower he learns to walk with prostheses and to fly a plane.

THÉMATA. Revista de Filosofía, Nº51 enero-junio (2015) pp.: 325-341

doi: 10.12795/themata.2015.i51.17 
as an end in itself - is the field to battle against the capitalist system and to prove the advantages of communism. The authentic communist is always a shock worker; on the contrary - idleness is an apparent symptom of a missing communist dedication. In such a conceptual paradigm the body of the worker is deprived of any individual features, it is the average mean product of the shaping, metaphysical communist spirit. From this point of view, the communist worker seems to be reduced to a particular body mechanism intended to carry out certain pragmatic actions (the necessary amount of work) but also to fulfill specific ideological functions (through his actions the worker exemplifies the requirements of the Party)

\section{The woman shock worker.}

This ideological evaluation of labour can just as clearly be traced in the figure of the woman shock worker. On $13^{\text {th }}$ Oct. 1944 - a little more than a month after the $9^{\text {th }}$ September ${ }^{7}$ - one of the first legislative initiatives of the new power is the passing of the "Regulations act for the equalization of rights of persons from both genders". It gives equal rights to both genders in the economic, state, cultural and social-political areas of life" (The Regulations Act 1944). This legislative document puts an unexpectedly rapid and decisive closure to the endeavours of Bulgarian women to obtain equality - endeavours, dating back to the end of the $19^{\text {th }}$ century. The Regulations Act literally copies all practices, established in the USSR after the revolution. Just like in Soviet Russia, women's emancipation in Bulgaria is not a formal juridical act. From normative documents to the establishment of increasing labour and public responsibilities; from privileges and awards to the operation of the propaganda media machine - all sorts of techniques for the organization of the public conscience and practice are systematically applied in this historical initiative. Soon after 09.09.1944 newspapers and magazines are virtually flooded with stories and images of heroines of labour: women brigade workers, women turners and reaping-machine drivers, women in military uniforms and so on; now we can see women who fulfill their communist duty not only near the traditional loom, but also in the until recently associated mainly with men occupations like tractor-driver, crane-drivers, reaping-machine driver, turner and so forth. A new subject irreversibly marginalizes the typical of women's magazines rubrics about fashion, cooking, motherhood, beauty tips and love stories. For years to come the only appropriate topic of any women's magazines will be the woman in a working uniform, the woman shock worker, who accomplishes labour feats.

[7] 09.09.1944 $\square$. is the date when the communist party takes over the power in Bulgaria.

THÉMATA. Revista de Filosofía, Nº51 enero-junio (2015) pp.: 325-341

doi: 10.12795/themata.2015.i51.17 
Workingwomen are represented as loving and caring mothers, but the stories about them lay a special emphasis on the labour achievements, on their dedication to work and to the construction of the socialist society. The children go to the background, these mothers are proud to say that from dawn to dusk their children are brought up and taken care of in kindergartens where the cares of the mother are completely unnecessary. A similar trend can be observed in the representation of woman as wife. She is a comrade of her husband; the ontology of 'comradeship' presumes a community of spiritual interests, not irrationality of sexual impulses; this is a kind of indirect relationship that is based on the mutual achievement of the supreme goal, not on the self-sufficiency of the love affection; it is a position that is near, not against in the whims of the erotic game. Thus, socialist woman is gradually stripped of various features of her feminity; in the first decade after 1944 her natural role of 'an object of desire' is almost entirely obliterated. After the war the variety of clothes that women can wear is by no means wide, but it is mainly the party's indignation with well-dressed bourgeois women, who have elegant hairdos and manicure, that hinders women from taking care of their physical appearance. In the first decade of the communist rule fashion is hardly ever mentioned - even in its pejorative aspect - it is only occasionally given as an example of capitalist indulgence, a form without any essence, adequately representing the emptiness of its consumers. The connection between woman's attractiveness and success, between beauty and popularity is discarded. These features of feminine nature are deemed suspicious, to say the least, because of their dangerous proximity to desire, moral corruption, lavish lifestyle and idleness. Respectively, what becomes an adequate visual and discursive representation of the militant, ascetic spirit of the woman builder of socialism is the image of the loom-operator (with a blue overall); the worker (in overalls, with a helmet); the woman brigadier (in a shapeless dress and head scarf); the public-organisation functionary (with tied hair and a strict face); the girls (looking the same in their quilted jackets and trousers, undistinguishable from one another or from their men colleagues) $)^{8}$.

While for the man worker the role of a fighter and heroic builder of the new society to a certain extent reinforces the traditional notion of masculinity, in the female version of this main socialist protagonist - the woman shock worker - the heroism in battles and labour definitely goes beyond the boundaries of what is traditionally seen as essential to feminine nature. The transformation of yesterday's women peasants into today's reaping-ma-

[8] "They look the same in their quilted jackets and trousers. They cannot be distinguished from the men. And just like the men, they are angry when the reinforced iron mixer is full and there aren't enough trucks to drive the reinforced iron away, they are furious when the machine gets jammed up in the muddy ditch" (Borisov 1961: 68)

THÉMATA. Revista de Filosofía, No51 enero-junio (2015) pp.: 325-341

doi: 10.12795/themata.2015.i51.17 
chine drivers, tractor-drivers and team leaders, of yesterday's tailors, spinners and housewives into construction-workers, turners and crane-operators - this seemingly chaotic and not very practical invasion of women in men's professions - is in fact relevant to the organic-communist layers of the project for the construction of the socialist society. The goal of this project is to reduce the complex taxonomy of various types of women - the proletariat woman, the intellectual, the housewife, the actress, the bourgeois lady, the peasant woman, the courtesan, the coquette - to the family-type woman-worker, as well as to level and even merge woman and man into one universal labour subject that will gradually lose any sexual characteristics. In reality, general labour service does not mean that women were supposed to massively start work in heavy industry. When the socialist authorities make secondary and higher education accessible to girls, they actually provide girls with serious opportunities for creative and intellectual development in areas that were earlier unattainable for them. This, however, does not discard the fact that - first, there are a lot of women who work in production sectors that are inappropriate to their physical abilities; secondly, numerous resources are wasted in attempts to legitimize the presence of women in these sectors.

These resources can hardly find their economic justification as lathe-work, metal production, hoist-operation, bulldozer-driving and scraper-dragging are activities, in which the use of men's power insures far higher productivity.

The attempt to obliterate gender differences through labour universalisation delineates a spot, specific of the socialist society. There the ideological factor does not simply exercise its traditional dominance over the other socially structural factors, but for a certain period of time it even transgresses the limitations set by nature. As if the amount of time and effort put by women into production indicates the strength and force of their communist spirit, their willingness to sacrifice.

\section{The brigade youth.}

The socialist rule brings about major changes in the life of young people. Education is now free and available for the masses, the study materials are supplied by the state. The state also provides jobs for secondary-school and university graduates; there is a considerable improvement in children's healthcare; the authorities guarantee longer maternity leave; they build numerous kindergartens, pre-school institutions and ensure after-school activities; children and adolescents have plenty of affordable places where they can relax and develop their talents. This considerate attitude to youth, however, is not a simple aspect of the practical implementation of a social project. In fact, as youth is generally associated with the future and is endowed with qualities 
like idealism, inexperience, innocence, intolerance to evil, lies and so on, the construction of an image of healthy, lively, happy young people is often used for propagating purposes. The efforts to win young people over as advocates of a particular political cause has an extensive history (Hitler Yunge, Scout organizations); in the years of the Cold War these efforts become an essential element of the ideological battle between the two worlds.

In the youth program, however, the socialist ideologists set considerably further-reaching goals than to simply construct an appropriate propagating image or to politically enlighten young people. Youth is considered to be the future brigade of communist-society builders. This status shifts the focus of the ideology - youth is not only to be won over but also 'trained' in the spirit of the communist cause. Youth is approached with a particular care; this care, however, is also mixed with a lot of caution. Due to the specificity of the age and the exceptional susceptibility to bodily temptations, youth is conceptualized both as an important human resource and a possible channel for ideological diversion' that has to be controlled. The brigade movement is one of the first attempts in that direction.

The goal of the brigade movement in Bulgaria is to urge young people to volunteer in the construction of strategic national sites obtaining minimal or no financial reward, thus contributing to the modernization of the socialist economy. The emblem of the movement is the red torch, the slogan - We build for the fatherland!

While in theory the participation in the brigades is voluntary, in practice it can hardly be interpreted as a simple result of the post-war youth enthusiasm. Here we should also bear in mind the various sanctions and incentives the state applies ${ }^{9}$.

The $5^{\text {th }}$ August 1946, when the First National Youth Building Brigade "George Dimitrov" is founded, is considered to be the start of the brigade movement. It takes a very short time for the brigade to expand to 25000 members (at least according to the party leaders and the propaganda). Although this information might be slightly exaggerated, for less than two years the brigades build numerous railways, tunnels, passes, roads, factories, electric power stations, dams and even towns - Dimitrovgrad is a fine example. The rough estimation of the work completed between 1947-1948 comes up to 3 billion leva, 1,5 billion out of which is economized by the state. The importance of the brigade movement, however, is by no means merely economical. It demonstrates one of the main functions of labour - labour educates. In the heyday of the movement - in May 1948 - its patron George Dimitrov makes a speech to a youth brigade delegation that visits him to hand in a promise, signed by 600

[9] One of the most significant incentives is a document that guarantees admission to university. This is especially important to young people with the so-called 'untrustworthy' bourgeois origin, who, by rule, are denied entrance in university in the first decades of the communist rule.

THÉMATA. Revista de Filosofía, Nº51 enero-junio (2015) pp.: 325-341

doi: 10.12795/themata.2015.i51.17 
000 people. In the speech Dimitrov states:

"I place great importance on the brigade movement. Not only because it turned out to be a major factor in the construction of our People's Republic, a serious action towards the realization of the socialist society in our country, but especially because it is an dispensable school for young people's education ... young people leave this movement as individuals that love labour, individuals with patriotic feelings, improved and strong" (Dimitrov 1948).

The speech of the Prime Minister does not simply summarise the results of the youth brigades, it also outlines the directions of a new political attitude to young people. This attitude sets new requirements, envisions new roles, assigns new tasks and lifestyle. In spite of their tender age, for a few weeks the brigadiers live in camps that provide very primitive accommodation, their work is extremely tough, predominantly manual - their tools are shovels, pickaxe, sickles ${ }^{10}$. The brigades are a disciplinary space, meant to train young people, to extract maximum production results from their bodies and to bring up their souls in the spirit of communist values. Adolescents are expected to turn their backs on their previous biases, inclinations, friendships, interests and to merge into one big army, where the person gains importance only as part of the whole, as an element of the labour machine. Although the young brigadiers are supposed to live together for a while, love relationships are strongly discouraged. In the above-mentioned speech George Dimitrov says:

„Careless and irresponsible relationships between young men and women are inappropriate and unacceptable... These brigades must develop an authentic strong comradeship between boys and girls, as well as shared love for labour and for our country." (Dimitrov 1948).

The ideological control is only a supplement to the seven-hour workday and the compulsory physical exercise. All these measures significantly limit the possibility for any sexual contacts. The universality of the uniforming comradeship that has to unite individuals in one class of people with common goals and tasks replaces the idea of a personal attitude - one that evolves from individual biases, inclinations or affinities. Future families of brigadiers are never seen as a result of dedication to a specific person but as a union of - more or less - replaceable people, "who have joined their hearts in labour, in creativity, with youth enthusiasm and mutual respect." (Dimitrov 1948). The youth brigade movement gradually recedes, engendering labour rhetoric rather than labour activity. Nevertheless, it remains the first successful implementation

[10] In his memoirs one of the brigadiers Lazarin Lazarov writes: „We had our daily targets to meet. And the way things were presented, it seemed that we might be sent to prison unless we met them. The food was badly cooked and with no meat - throughout the whole brigade we didn't taste meat more than twice. Everything had to be done on command but the least expected thing was the punishment for any disciplinary offence. (Lazarov 2004).

THÉMATA. Revista de Filosofía, Nº51 enero-junio (2015) pp.: 325-341

doi: 10.12795/themata.2015.i51.17 
of the authorities' vision for the ideal type of socialist youth - an enormous collective with common goals, united will, conscience and a value system, an imposing machine of various connected working mechanisms.

$* * *$

In the first months after 09.09.1944 the new rule begins to construct not only the positive image of the communist shock-worker but also its negative counterpart. The socialist propaganda quickly and resolutely defines its enemies - the class enemy is locally represented by the remnants of the fascist-like bourgeoisie; it also persists globally in the western capitalist world as well as in the surreptitious, silently sabotaging the socialist construction 'non-working' elements. It is common that these personages intermingle into the image of the 'bourgeois-like decadent', who has a decaying lifestyle and excludes himself from the enthusiasm of the communist creativity. The socialist ideologists see in the propensity of these people to live an easy and stripped of any labour habits life the main reasons for the resilience of the residue elements of bourgeois culture and bourgeoisie in general. The broadly discussed in 1946 "Bill of labour mobilization of idle people" envisions obligatory labour service for the ones who are reluctant to participate in the widespread working campaigns; it targets vagrants, 'women that have turned their backs on normal life"11, as well as the loitering and intellectual-like young people whose conduct is defined as the first step to criminality, espionage and ideological diver$\operatorname{sion}^{12}$. After the bill in August 1946 was passed these categories of Bulgarian citizens are forcefully engaged in the construction of the new socialist society - the building of roads, factories, railways, residential homes and bridges. The ones trying to get away with labour service are sentenced to prison or fined.

[11] This is the euphemism that the Bulgarian socialist discourse uses to refer to prostitutes and women that are financially supported by their partners; women who do not work but spend their free time in the few left bars and restaurant

[12] In a speech discussing the bill Minister of Interior Affairs Anton Yugov frankly states: "The bill (...) aims to defeat those leeches, those loafers and idlers, whose lifestyle disrupts the social order and security, thus, we want to cultivate sound habits and to reinforce sound public morality. The bill concerns the idlers and loafers, who have never worked in their life; those who find easy and dishonest ways to make a living without working..., the main aim of the bill is to correct. Life has pushed these people in the mire of moral corruption, we want to pull them out and to teach them to work hard, to reintegrate them and return them to our society as decent citizens, who make an honest living, whose work contributes to the democratic development of the country... Those who do not participate in the voluntary labour service will be forcefully mobilized and sent to labour groups. Even if somebody is wrongfully sent there, this shall be no big mistake, as it won't hurt if this person is compelled to work for the benefit of his country for six months. What do you think they will do? In the bill it is explicitly stated - they will build roads, railways, homes and factories... There is no harm in that. (Yugov 1946)

THÉMATA. Revista de Filosofía, Nº51 enero-junio (2015) pp.: 325-341

doi: 10.12795/themata.2015.i51.17 
The goal of the bill, explicitly stated by Minister of Interior Anton Yugov, is that 'the joy of labour' should correct those that are sinking in the mire of sin.

The bill of Labour mobilization is closely related to the 'Bill of labour correction institutions', published in 1945. The latter legitimizes the foundation of labour-correction institutions - better known as labour camps. Along with criminal recidivists these camps detain prostitutes, procurers, souteneurs, gamblers, vagrants, idlers - all the so-called 'non-working elements'. The goal of these camps is to divert those sent there from their 'immoral criminal intentions and habits, to teach them to work hard and to heighten their moral and intellectual awareness".

These two bills, along with the propaganda machine, transform the 'idlers', 'loafers' and 'girls with loose behaviour', presented mainly through the images of 'swings' and 'zozas', into key notions of the period ${ }^{13}$. They designate the negative image of the woman-worker, the stigmatized counterpart of the young brigadier. The positive and the negative image oppose joy to sexual corruption, labour heroism to card and backgammon games, cultural dances (folklore and classical) to moronic twisting, self-sacrifice to dishonest flirts and onenight stands. Brigadiers embody the socialist ideal of youth - they are eager to sacrifice their personal interests for the common good, whereas 'zozas' and 'swings' are degenerated individuals who place the needs of their private, egotistical bodies above the demands of the society. "Swings" obtain their name from the popular jazz style, but 'swing' is no longer a musical style, it symbolizes the unsound bourgeois erotica, its sensual intensity and futile hedonism, its decaying lifestyle. The healthy, agile and thriving is confronted with the sick, corrupted, twisted and decaying. These two bodily characteristics have a specific referent ${ }^{14}$.

[13] "Swings" and "zozas" become especially popular in the late 1940s and early 1950s. The names designate those young people who are mainly interested in leisure, non-work activities. The term 'swing' comes from the popular in the 1930s musical style, but in Bulgaria 'swing' is generally associated with dandy boys that have a bohemian lifestyle. The word "zoza", however, has an unclear origin. It is considered to be the female version of the 'swing'.

[14] These are recurring motifs in the communist propaganda. They can be traced not only in openly ideological articles but can also be read in 'expert' opinions in the press. The official newspaper of the communist party "Rabotnichesko delo" directly relates idleness to criminality, thus supporting the "Bill of labour mobilization". What characterizes the anonymous editorials of the newspaper is that they usually reproduce word by word the directives of the higher party organs and are intended to prepare the public for the unpopular measures of the authorities, giving them an air of general support and people's approval.

„The demonstrations of idleness, laziness and parasitism are getting more and more intolerable. There are people who do not want to overcome these disgraceful habits from the past. The labour enthusiasm of the other people does not touch them. They do whatever it takes to get away with productive work. They are sarcastic about shock workers and competition. It is obvious that these idlers, loafers and parasites are the real evil... idleness and loitering are dangerous infection that spreads everywhere and reduces the work enthusiasm among the others. In fact,

THÉMATA. Revista de Filosofía, No 51 enero-junio (2015) pp.: 325-341

doi: 10.12795/themata.2015.151.17 
The collective working organism and its components are always healthy, the self-isolating, enjoying life individual - sick and degenerated. Therefore, brigadiers are always described as joyful, upbeat, strong and agile. This representation rules out any sexual looseness and intoxication, bitter-sweet lustful erotica. On the contrary, the corporal aspect of the body as a carrier of instincts and passions is closely related to disease symptoms - degeneration, decay, sleep talking, morbidity, insanity. These symptoms are to be found in the dying bourgeois class but also in those individuals that have diverted from the socialist public and labour norm.

Political resistance/apoliticity, ideological diversion, idleness and moral decay are mutually replaceable notions. "Women with non-labour incomes" are not simply marginalized by the socialist hierarchy of ideal images of women; swings and zozas are not simply too lazy to take part in the brigade movement and too eager to listen to imperialist music, to twist with movements that resemble 'erotic bacchanalia'. They are considered socially unsound people who threaten the socialist state and whose treatment through labour may transform them into normal, socially reliable citizens. According to the two above-mentioned bills - the bill of labour mobilization of idlers and the bill of labour correction institutions - labour is seen as a basic value in the communist society. Not only does it have pragmatic influence on reality, but it can also treat and cure those who, unaware of the danger of their disease, want to avoid labour activities. In order to be cured these ignorant people are forced to build factories, plants, roads and sometimes even happen to be sent to labour camps.

The detainees form a heterogeneous mass consisting of at least three separate groups. The first comprises hardened criminals; the second - political offenders: ex-political leaders; representatives of the agricultural movement, who oppose to being included in the cooperative unions; even communists and active fighters, who are dissatisfied with the party politics - all these are politically aware individuals who are ready to take responsibility of their anti-communist activities. The third group consists of people who could not predict the consequences of their bohemian lifestyle, of their parties, fashionable clothes, swing and twist or rock'n' roll dances; or women, who tend to take advantage of their appearance in order

there is a very thin line between idleness and laziness and overt criminality. (Against idleness and loitering, 1947)

Venelin Krastev - a communist musicologist, author of numerous ideologized histories of music - gives his professional opinion on the pathological character of American jazz and the therapeutic impact of Soviet pop music: "Today the issue about jazz hits is a matter of getting rid of the bourgeois residues that penetrate through this music among certain parts of our youth. It is also a matter of battling against the deeply reactionary and decadent American jazz music. It comprises in itself the general decay and decadence of dying bourgeoisie. The most widespread and disgusting style of American jazz music is swing... Swing music tells the story of a painful experience, it is the result of the lowest instincts... Soviet dance and pop music is music for the masses. It does not whisper lustful thoughts, it does not blur the conscience with sugarcoated melodies and tribal rhythms. Soviet music speaks loudly about the joyful new life of working people." (Krastev 1952: 57)

THÉMATA. Revista de Filosofía, No51 enero-junio (2015) pp.: 325-341 doi: 10.12795/themata.2015.i51.17 
to earn the so-called 'non-labour incomes'. It is precisely these young people that are subsumed under the rather broad, flexible and easy to manipulate categories 'idlers', 'hooligans' and 'other decaying elements'. The organs of the Ministry of Interior Affairs directly determine their destiny while neglecting all human rights - the presumption of 'innocent until proven guilty', the right of legal defence, the separation between executive and legislative power. Many of the 'idlers' and political offenders prefer to plead guilty of a criminal offence, so that they serve a short period of time in prison rather than be sent for an unlimited period of time to a labour camp without any court decision. The detention in labour camps is supposed to last 6 months but it can be repeatedly extended with a new order. (Bill of labour correction institutions 1946).

To a certain extent the authorities are more tolerant to criminal offenders. In general, criminal offence is interpreted as a private crime, the crime committed by the idler is directly aimed at disrupting the order of the state, respectively aimed at undermining socialism.

The one is a crime against the person; the other - a crime against society. The lenience towards the criminal offender has its specific reasons - the offender is to be punished for a singular offence; on the contrary, what has to be penalized in the political misdemeanour is not the single act but the whole conduct. It is by no means accidental that ideological offenders are compared to hardened criminals. 'Hooligans', 'prostitutes', 'idlers' and 'decaying elements' are sent to labour camps not because of what they have committed but because of what they are; not for actions but for propensities, inherent to their lifestyle, their habits and modes of embodiment. These people are suspicious because their crimes cannot be reduced to the external action. Their deeds symbolize the internal moral devastation. The individuals from this group are conceived of as infected by moral and ideological contamination. Therefore, internment, compulsory labour service and detention in specific places are seen as significant functions to protect the public. ${ }^{15}$ Above all, they limit the range of the epidemics; secondly, the compulsory labour activities and abstention teach these people out of their 'immoral habits'; thirdly, they serve as a warning about the dangerous consequences of such behaviour. What these labour camps provide for the less infected is a variety of treatments (the official interpretation is that this is a correction through labour, in reality this involves work in harsh conditions and regular beatings; in more extreme situations the offenders risk never leaving the place ${ }^{16}$. (Sugarev 1999: 237 - 239)

[15] According to art.14 from „Decree of the People's Militia”, functioning between 1955 and 1977, people who do not have a permanent address may be detained and interned for a minimum of 6 months. Art. 14 is closely synchronized with the bill of labour institutions. After the abolishment of the camps, the article legitimizes the detention and internment in the formally non-existent camp in Belene (Sugarev 1999: 388 - 389).

[16] A recurring, and somewhat mythologised in the recollections of the inmates, story is that of a seventeen-year-old boy, sent to a labour camp by his father - an active fighter and colonel. The

THÉMATA. Revista de Filosofía, Nº51 enero-junio (2015) pp.: 325-341

doi: 10.12795/themata.2015.i51.17 
Along with the obvious ethical dichotomy 'love for labour' - 'laziness', the presented legal and journalist texts outline another major division. This is the theoretically unarticulated but practically made distinction between the efficient, productive body - the body-machine, and the body that is a source of impulses, passions and pleasure - the body-flesh. The members of these two dichotomies are arranged in a strict proportional order and are endowed with an array of predicates. In the ideological scheme of communism idleness is a treacherous ground which gives birth to all moral and physical vices; the internal corruption, on its own right, is inevitably connected to laziness. The fundamental for the socialist society labour activity is considered to be not only a result of a highly productive bodily mechanism, but also a precondition for the optimal status of this mechanism.

\footnotetext{
„The human machine follows the same principles as any other rationally designed machine. Any machine is meant to have a specific capacity, to give useful output. Obviously, labour is the necessary element of life itself" - this is what Stoyan Kadiev (MD) states in an article published in the heyday of the brigade movement and labour mobilizations. The article claims to reveal scientific truths, whereas the only reason why it can provoke any interest here is the introduction of the metaphor 'human machine'. (Kadiev 1947).
}

In fact, although this figure of speech is not so commonly used, the notion significantly shapes the communist conception of the body. Morning physical exercise, mass physical-culture events, sport at the work place, regular medical examinations at work (all these are in a sharp contrast to the primitive conditions in brigade camps, an unbearable workload women in factories are submitted to, corporal punishments and food shortages in labour camps) are meant to demonstrate the party's care for the physical capability of the body mechanism but also to show its puritan attitude (especially in the first 10-15 years after 1944) to bodily pleasures and enjoyment. Health, liveliness and physical efficiency are definitions that do not describe the individual bodies of the egotistical idling and enjoying themselves people but the well-functioning body-machines. The latter are supposed to achieve their labour goals, to be rationally used in the grand construction of socialism. Against this background it becomes clear that the implicit (though yet unattained) ideal of the communist worker reduces the personality of each citizen to a stripped of any individuality, physical body features, emotionality and sexuality machine that is part of the incessant labour activity. Through the tedious repetition of oppositions like

father sends the boy to the labour correction camp so that the boy turns his back on his youthful whims through hard work. According to the recollections on the third day the boy dies because of severe beatings. When the colonel learns about his son's death, he tears apart his epaulets. (Sugarev 1999: 277 - 389).

THÉMATA. Revista de Filosofía, Nº51 enero-junio (2015) pp.: 325-341 doi: 10.12795/themata.2015.i51.17 
'labour'-'idleness', 'health' - 'disease', 'liveliness'-'decay', 'high morality'-'lifestyle devastation', 'public efficiency'-'egotistical individualism' the communist propaganda presents all actions that distract the individual from labour activities as a real threat and an attack against the pillars of the socialist society. Still, there is one more thing we have to bear in mind. If idleness and fun distractions interfere with the fulfillment of work activities - therefore they should be morally and normatively sanctioned - this logical statement can be reiterated the other way around: the importance of work activities should be measured not only with regard to their practical results but also with regard to their educational function.

Here we can observe one of the vicious circles of Bulgarian socialism. Bodily impulses and pleasures have a negative value since they distract the person from the participation in collective work for the construction of the new society. Collective work itself should educate and develop the socialist person making him resistant to any bodily or moral temptations.

This ambivalent attitude to the body-machine, on the one hand, and to the hedonistic body, on the other, has a long history in the modern political thought and practice. This history, however, is articulated in rhetoric different from the communist ideology. What Weber describes as the protestant moralistic ethos of self-obliteration in labour and self-denial of pleasure appears to be related to the socialist apology of labour. Foucault's narrative about the birth of the body-machine in modernity can also be deployed as a line of thought giving us a better understanding of communist practices. According to Foucault two discursive registers engender the disciplined body - the anatomo-metaphysical, having its roots in Decart's analyses; and the techno-political, stemming from military, school and hospital rules, as well as from practical methods for control and correction of body actions. While anatomo-metaphysics discusses the body as an object of investigation, technopolitics submits it; it aims to condense it and to extract all its productive powers. The focal point of the analysed and manipulated body is the image of the 'body-machine' by La Mettrie. Here the body becomes not only a material object of study but also a mechanized automaton, whose main predicate in both cases is its docility. Thus, modernity generates docile, disciplined bodies that can be studied and perfected, invaded and used (Foucault 1998: 146)

Discipline is a concept that the ideological matrix of communism reproduces again and again. The techniques for body submission also play an important role in the political and production practices. Engendered in the scientific traditions of the Enlightenment, socialism inherits plenty of the modern theoretical intuitions for the body-machine, as well as the political techniques for its submission. Nevertheless, there are significant differences between the socialist attitude to the "body-machine' and early capitalist visions. Foucault claims that "Discipline intensifies the powers of the body (in terms of economic 
efficiency) and reduces them (in terms of political submission)" (Foucault 1998: 148). Totalitarian societies inherit mainly the second part of this correlation. Galvanizing to the extreme the political submission, it ignores the utilitarian criteria, thus transforming the docile body into an end in itself. For the worker the practical benefit from hard work is minimal since salaries in Bulgaria are more or less the same, what's more, the market cannot offer many goods because of the constant goods shortages. The more intensive workload and the higher productivity are only symbolically appraised by the communist power: shock-workers obtain various orders, medal, certificates, none of which has its financial equivalent. Even if we consider the communist postulate for hard work for the general good (and not for the personal gain), practically the socialist economy loses the competition with the capitalist world.

In spite of its eloquent rhetoric, in spite of the indisputable achievements in socialist construction and modernization after 1944, communist labour (especially after the mid-1950) does not concentrate on economic results ${ }^{17}$; rather, it generates metaphors and symbols, it inculcates and educates.

Thus, the 'normal' body of early socialist Bulgaria is docile, asexual and impersonal. It possesses deeply rooted habits and strict discipline; rather than producing practical results, it is prepared to demonstrate loyalty; rather than producing, it is ready to simulate productivity ${ }^{18}$. In its communist version - the labour hero, the woman shock-worker, the upbeat brigadier - the body-machine is envisioned as an aimlessly working automaton, powered by a grandiose political subject.

[17] On the topic of socialist productivity and the achievements of the Bulgarian socialist economy see Ivanov, R., The economy in the epoch of socialism; Hristov H., The Secret Bankruptcy of the Communism.

[18] One of the researchers of Bulgarian socialism Vladislav Todorov says; "Plants are not intended to produce goods. They produce symbolic meanings. They symbolize industrialization. Industry is a type of ideology and the plants are the output of this ideology. They generate goods shortage but also overproduction of words and labour-like spells. (Todorov 1991:14)

THÉMATA. Revista de Filosofía, No51 enero-junio (2015) pp.: 325-341

doi: 10.12795/themata.2015.i51.17 


\section{References:}

Against idleness and loitering. Editorial. 1947. Rabotnichesko delo, 01.07.1947.

Bill of labour correction institutions 1945. In: Legal Code from 09.09.1944 to 15.12.1945. Sofia: Darzhavna pechatnitsa, $1947(\mathrm{Bg})$.

Bill of labour mobilization of idle people. 1946. In: Legal Code of Ministry of Interior. Sofia: Institut Naroden strazh, 1948 (Bg).

Borisov, S., 1961. The girls from the great building. Lada, 4: $25-27$ (Bg).

Dimitrov, G., 1948. The Brigade movement trains the youth. Narodna mladezh, 04.05.1948 (Bg).

Dimitrov, G., 1947. We must fight against idleness and parasitism. Rabotnichesko delo, 28.06.1947 (Bg).

Foucault, M., 1996. Madness and Insanity: History of Madness in the Classical Age. Pleven: EA, 1996 (Bg).

Foucault, M., 1998. Discipline and Punishment. The Birth of the Prison. Sofia. University publishing house „St. Kliment Ohridski”, 1998 (Bg).

Hristov H., 2007. The Secret Bankruptcy of the Communism. Sofia: Siela, 2007 (Bg).

Ivanov, R., 2007. The economy in the epoch of socialism. Dialog, 7: 14$51(\mathrm{Bg})$.

Kadiev, St., 1947. The labour school - the best school for youth's training. Rabotnichesko delo, 09.07.1947 (Bg).

Krastev, V., 1952. About dance and pop music. Mladezh, 2: 57 - 64 (Bg).

La Mettrie, J., 1981. Machine Man. Sofia: Nauka i izkustvo, 1981 (Bg).

Lazarov, L., 2004. Memories about communism. In: Media Times Review. http://www.mediatimesreview.com/august04/LazarinLazarov.php.

Naydenov, G., 1948. The bourgeois corruption among youth. Mladezh, 1: $3-8(\mathrm{Bg})$.

Regulations act for the equalization of rights of persons from both genders. 1944. In: Legal Code from 09.09.1944 to 15.12.1945. Sofia: Darzhavna pechatnitsa, $1947(\mathrm{Bg})$.

Sugarev, E., 1999. The Bulgarian Gulag. Sofia: Demokratsiya, 1999 (Bg).

Todorov, V., 1991. Adam's complex. Sofia: Ivan Vazov, 1991 (Bg).

To educate the masses in socialistic attitude to labour. Editorial. 1954. Rabotnichesko delo, 25.11.1954 (Bg).

Weber, M., 1993. The Protestant Ethic and the Spirit of Capitalism. Sofia: Hermes-7, 1993 (Bg).

Yugov, A., 1946. Speech discussing the "Bill of labour mobilization of idle people”. Rabotnichesko delo, 08. 08. 1946 (Bg). 
